\author{
Д. Д. Тищенко
}

Дніпропетровський національний університет

\title{
ДОСЛІДЖЕННЯ ГІСТОХІМІЧНИХ ОСОБЛИВОСТЕЙ ОДНОРІЧНИХ ПАГОНІВ ПРЕДСТАВНИКІВ РОДУ СОTONEASTER
}

\begin{abstract}
Наведено матеріали досліджень особливостей анатомічної будови, характеру крохмальних відкладень і ступеня здерев'яніння однорічних пагонів представників роду Cotoneaster Medic. (кизильник), інтродукованих у ботанічному саду ДНУ. Встановлено стійкі та нестійкі до низьких температур види кизильників.
\end{abstract}

Research data of the anatomic structure, the character of starch deposits and lignification's degree of one-year sprouts of representatives of the Cotoneaster Medic. genus, introduced in the DNU Botanical garden, are presented. Frigostable and frigolabile cotoneasters species are determined.

\section{Вступ}

Для степової зони України, де природний склад дендрофлори обмежений, збагачення флори деревних рослин новими цінними видами має велике значення для зеленого будівництва [4]. До перспективних рослин для такого використання належать представники поліморфного, ще мало вивченого роду Cotoneaster Medic. Тому визначення рівня їх адаптації до природних факторів нового району зростання $\epsilon$ актуальним [2]. Основні дослідження та публікації з оцінки успішності інтродукції цього родового комплексу в умовах України стосуються морфометричних і екологічних показників; анатомічні та гістохімічні критерії досліджені мало. Використання критеріїв змін гістологічної будови пагонів рослин може не тільки дозволити встановити ступінь адаптованості виду до умов зростання, а й визначити пристосувальні механізми та оцінити перспективи використання досліджуваного виду в озелененні [5]. Особливої уваги заслуговують клітинні включення, які утворюються в результаті пристосувальних реакцій до несприятливих умов середовища. Їх присутність характеризує фізіологічний стан клітини. Тому наявність і локалізація, наприклад, крохмальних зерен у рослині може служити критерієм готовності іï до зимівлі [8; 9].

Мета даної роботи - виявити особливості структури однорічних пагонів рослин, встановити характер крохмальних відкладень і ступінь здерев'яніння пагонів.

\section{Матеріал і методи досліджень}

Для анатомічних і гістологічних досліджень однорічних пагонів використовувалися п'ять видів кизильників із різних регіонів зростання - Cotoneaster horizontalis, C. nitens, C. zabelii (Північно-Східний Китай), C. lucida (Сибір, Балкани), C. multiflora (Середня Азія). Усі види високо декоративні та поліморфні $[1 ; 3 ; 10]$.

Рослинний матеріал збирали у липні, вересні та жовтні 2005 року, фіксували за загальновідомими методиками [6]. Виміри абсолютних розмірів тканин проводили за допомогою окуляр-мікрометра. На поперечних зрізах п'яти пагонів у трьох повторностях вимірювали радіус пагона та серцевини, товщину покривної тканини, коленхіми первинної кори, паренхіми, твердого та м'якого лубу, ксилеми (мкм), а також кількість шарів коленхіми, кількість і довжину відрізків твердого лубу, кількість і діаметр судин ксилеми [5].

Оскільки для аналізу анатомічної реакції рослини на зовнішній вплив абсолютних розмірів недостатньо, доцільно перевести їх у відносні величини шляхом розрахунку площі кожної тканини (у відсотках від радіуса всього пагона) [7]. Середнє розраховували тільки для гістологічних комплексів, не враховуючи радіус пагона. Адже

Вісник Дніпропетровського університету. Біологія, екологія.

Vìsnik Dnìpropetrovs'kogo unìversitetu. Serìa Bìologiâ, ekologîâ Visnyk of Dnipropetrovsk University. Biology, ecology. Vìsn. Dnìpropetr. Unìv. Ser. Bìol. Ekol. 2007. 15(1).

ISSN 2310-0842 print ISSN 2312-301X online www.ecology.dp.ua 
об'єднати радіуси було б статистично невірним: вони мають незалежне походження та слугують тільки як початкова точка для розрахунків.

Ступінь здерев'яніння тканин однорічних пагонів досліджених об'єктів визначали візуально за інтенсивністю забарвлення при реакції лігніну на флороглюцин за трибальною шкалою [5]. Ступінь крохмальних відкладень у тканинах однорічних пагонів визначали візуально за інтенсивністю забарвлення при реакції крохмалю на розчин Люголя за трибальною шкалою [8].

\section{Результати та їх обговорення}

У більшості видів встановлено (табл. 1) ріст покривної тканини та коленхіми кори у жовтні порівняно з липнем, що говорить про зміцнення осьових органів для захисту в зимовий період. Кількість шарів коленхіми максимальна у C. nitens $(3,5-4,5)$ і мінімальна у $C$. horizontalis i $C$. multiflora $(2,0-3,0)$. Залишки епідермісу з епідермальними волосками у вигляді сосочків зберігаються до вересня в усіх видів. У жовтні вони присутні у C. horizontalis i C. multiflora.

Для обстежених видів, крім C. multiflora, наявна тенденція до зменшення товщини вторинної кори, а також зміни специфічних особливостей ії закладання. Зокрема, у C. horizontalis зменшення товщини вторинної кори відбувається за рахунок м'якого лубу (на 53,6 \%). Розміри серцевини пагона суттєво не змінюються. Спостерігається тенденція збільшення паренхімної тканини у період спокою порівняно з фазою вторинного росту за рахунок зменшення луб' яних і деревинних гістологічних комплексів.

Табличя 1

Показники відносного розвитку тканин (\%) однорічних пагонів видів роду Cotoneaster

\begin{tabular}{|c|c|c|c|c|c|c|c|c|}
\hline Вид & Дата & $\begin{array}{c}\text { Покривна } \\
\text { тканина }\end{array}$ & Коленхіма & Паренхіма & $\begin{array}{c}\text { Твердий } \\
\text { луб }\end{array}$ & $\begin{array}{c}\text { М'який } \\
\text { луб }\end{array}$ & Ксилема & Серцевина \\
\hline \multirow{6}{*}{ C. horizontalis } & VII. & $3,3 \pm$ & $5,2 \pm$ & $11,7 \pm$ & $5,2 \pm$ & $16,4 \pm$ & $26,6 \pm$ & $32,4 \pm$ \\
\hline & 2005 & 0,31 & 0,51 & 2,15 & 0,64 & 1,92 & 3,61 & 1,71 \\
\hline & IX. & $3,7 \pm$ & $5,1 \pm$ & $16,2 \pm$ & $6,5 \pm$ & $11,5 \pm$ & $14,1 \pm$ & $27,4 \pm$ \\
\hline & 2005 & 0,64 & 0,01 & 1,02 & 0,32 & 1,02 & 1,95 & 2,62 \\
\hline & X. & $3,8 \pm$ & $5,2 \pm$ & $16,4 \pm$ & $5,2 \pm$ & $8,8 \pm$ & $9,6 \pm$ & $36,6 \pm$ \\
\hline & 2005 & 0,56 & 0,42 & 0,10 & 0,48 & 0,54 & 0,01 & 9,83 \\
\hline \multirow{6}{*}{ C. lucida } & VII. & $3,7 \pm$ & $4,2 \pm$ & $12,4 \pm$ & $6,0 \pm$ & $9,3 \pm$ & $32,0 \pm$ & $29,0 \pm$ \\
\hline & 2005 & 0,31 & 0,22 & 0,91 & 0,41 & 1,02 & 1,91 & 2,11 \\
\hline & IX. & $5,1 \pm$ & $6,7 \pm$ & $15,1 \pm$ & $4,9 \pm$ & $9,8 \pm$ & $13,8 \pm$ & $27,2 \pm$ \\
\hline & 2005 & 0,22 & 0,74 & 0,42 & 0,10 & 0,01 & 0,92 & 1,91 \\
\hline & X. & $5,3 \pm$ & $8,4 \pm$ & $21,4 \pm$ & $5,3 \pm$ & $9,0 \pm$ & $29,9 \pm$ & $22,1 \pm$ \\
\hline & 2005 & 0,83 & 0,41 & 1,12 & 0,42 & 0,80 & 0,83 & 1,91 \\
\hline \multirow{6}{*}{ C. multiflora } & VII. & $4,8 \pm$ & $6,7 \pm$ & $8,1 \pm$ & $7,2 \pm$ & $9,6 \pm$ & $33,0 \pm$ & $27,3 \pm$ \\
\hline & 2005 & 0,53 & 0,01 & 1,32 & 0,73 & 1,72 & 1,11 & 1,92 \\
\hline & IX. & $4,8 \pm$ & $7,0 \pm$ & $14,1 \pm$ & $6,6 \pm$ & $20,2 \pm$ & $30,5 \pm$ & $25,6 \pm$ \\
\hline & 2005 & 0,62 & 0,01 & 0,01 & 0,24 & 0,81 & 3,11 & 2,72 \\
\hline & $\mathrm{X}$ & $4,4 \pm$ & $6,0 \pm$ & $12,2 \pm$ & $8,1 \pm$ & $13,0 \pm$ & $14,7 \pm$ & $26,6 \pm$ \\
\hline & 2005 & 0,34 & 1,00 & 0,82 & 0,65 & 0,04 & 1,31 & 1,93 \\
\hline \multirow{6}{*}{ C. nitens } & VII. & $5,4 \pm$ & $7,0 \pm$ & $19,9 \pm$ & $5,9 \pm$ & $5,1 \pm$ & $17,0 \pm$ & $36,0 \pm$ \\
\hline & 2005 & 0,91 & 0,31 & 1,31 & 0,24 & 0,31 & 0,82 & 2,63 \\
\hline & IX. & $4,1 \pm$ & $8,8 \pm$ & $16,1 \pm$ & $6,5 \pm$ & $6,4 \pm$ & $14,7 \pm$ & $28,5 \pm$ \\
\hline & 2005 & 0,61 & 0,92 & 1,54 & 0,12 & 0,21 & 1,33 & 2,85 \\
\hline & X. & $4,7 \pm$ & $9,6 \pm$ & $17,3 \pm$ & $5,9 \pm$ & $6,7 \pm$ & $25,4 \pm$ & $26,2 \pm$ \\
\hline & 2005 & 0,81 & 0,01 & 1,22 & 0,42 & 0,01 & 4,11 & 2,35 \\
\hline \multirow{6}{*}{ C. zabelii } & VII. & $4,4 \pm$ & $7,9 \pm$ & $19,9 \pm$ & $6,4 \pm$ & $11,8 \pm$ & $14,0 \pm$ & $27,0 \pm$ \\
\hline & 2005 & 0,32 & 0,67 & 0,72 & 0,41 & 0,62 & 0,65 & 1,21 \\
\hline & IX. & $5,7 \pm$ & $8,3 \pm$ & $16,7 \pm$ & $5,0 \pm$ & $8,7 \pm$ & $18,2 \pm$ & $31,9 \pm$ \\
\hline & 2005 & 0,65 & 0,01 & 0,01 & 0,01 & 1,06 & 0,03 & 0,93 \\
\hline & X. & $5,9 \pm$ & $11,7 \pm$ & $14,6 \pm$ & $6,7 \pm$ & $10,4 \pm$ & $20,0 \pm$ & $27,3 \pm$ \\
\hline & 2005 & 0,51 & 0,51 & 1,34 & 0,09 & 0,84 & 0,01 & 1,03 \\
\hline
\end{tabular}

Вісник Дніпропетровського університету. Біологія, екологія.

Vìsnik Dnìpropetrovs'kogo unìversitetu. Seriâ Bìologîa, ekologîâ Visnyk of Dnipropetrovsk University. Biology, ecology. Vìsn. Dnìpropetr. Unìv. Ser. Bìol. Ekol. 2007. 15(1).

ISSN 2310-0842 print ISSN 2312-301X online www.ecology.dp.ua 
Розмір ксилеми добре корелює із середнім діаметром ії судин (табл. 2). Максимальний діаметр судин відмічено у представників $C$. horizontalis і $C$. nitens. Дуже дрібні, іноді зовсім недиференційовані судини у $C$. zabelii. Зв'язку між діаметром судин і їх кількістю у тканині не помічено. Спостерігається збільшення впорядкованості розміщення судин у ксилемі у фазі спокою. Це говорить про сформованість пагона та підготовку рослини до зимівлі.

Таблиия 2

Основні характеристики провідних елементів однорічних пагонів видів роду Cotoneaster

\begin{tabular}{|c|c|c|c|c|c|}
\hline Вид & Дата досліду & $\begin{array}{c}\text { Товщина } \\
\text { ксилеми, } \\
\text { мкм } \\
\end{array}$ & Кількість судин & $\begin{array}{c}\text { Середній діаметр } \\
\text { судин, мкм }\end{array}$ & $\begin{array}{c}\text { Максимальний } \\
\text { діаметр } \\
\text { судин, мкм } \\
\end{array}$ \\
\hline \multirow{3}{*}{ C. horizontalis } & VII.2005 & $244,0 \pm 33,2$ & $45,2 \pm 4,2$ & $12,3 \pm 0,62$ & $19,3 \pm 2,75$ \\
\hline & IX.2005 & $114,2 \pm 15,1$ & $38,4 \pm 2,3$ & $8,5 \pm 0,33$ & $16,4 \pm 0,11$ \\
\hline & X.2005 & $82,0 \pm 0,1$ & $32,3 \pm 1,1$ & $9,2 \pm 0,31$ & $16,4 \pm 0,01$ \\
\hline \multirow{3}{*}{ C. lucida } & VII.2005 & $298,3 \pm 18,2$ & $44,5 \pm 2,3$ & $10,7 \pm 1,06$ & $15,6 \pm 0,86$ \\
\hline & IX.2005 & $115,2 \pm 8,1$ & $38,8 \pm 2,2$ & $4,1 \pm 0,01$ & $9,3 \pm 0,82$ \\
\hline & X.2005 & $158,4 \pm 4,5$ & $45,2 \pm 2,1$ & $9,8 \pm 1,05$ & $14,8 \pm 1,05$ \\
\hline \multirow{3}{*}{ C. multiflora } & VII.2005 & $203,5 \pm 7,3$ & $46,3 \pm 2,3$ & $8,2 \pm 0,01$ & $12,3 \pm 0,01$ \\
\hline & IX.2005 & $178,6 \pm 18,3$ & $46,5 \pm 2,4$ & $9,0 \pm 0,85$ & $13,1 \pm 1,56$ \\
\hline & X.2005 & $93,5 \pm 8,5$ & $46,3 \pm 2,2$ & $8,2 \pm 0,01$ & $12,3 \pm 0,01$ \\
\hline \multirow{3}{*}{ C.nitens } & VII.2005 & $103,1 \pm 5,0$ & $49,6 \pm 3,2$ & $13,1 \pm 1,74$ & $18,0 \pm 1,10$ \\
\hline & IX.2005 & $93,2 \pm 8,4$ & $38,2 \pm 3,6$ & $12,3 \pm 0,11$ & $16,4 \pm 0,11$ \\
\hline & X.2005 & $217,3 \pm 35,2$ & $62,4 \pm 2,4$ & $9,8 \pm 1,11$ & $19,7 \pm 1,55$ \\
\hline \multirow{3}{*}{ C. zabelii } & VII.2005 & $89,4 \pm 4,2$ & $42,5 \pm 2,2$ & $8,7 \pm 0,55$ & $15,0 \pm 1,42$ \\
\hline & IX.2005 & $82,0 \pm 0,1$ & \multicolumn{3}{|c|}{ багато слабкодиференційованих } \\
\hline & X.2005 & $123,0 \pm 0,1$ & $55,8 \pm 2,5$ & $8,2 \pm 0,1$ & $12,3 \pm 0,1$ \\
\hline
\end{tabular}

Виявлено наступні особливості будови однорічних пагонів різних видів.

C. horizontalis. Відмічено сильний волосяний покрив усіх пагонів, зменшення діаметра судин ксилеми у вересні, збільшення відсотка паренхімної тканини та м'якого лубу порівняно з деревиною у жовтні.

C. lucida. Спостерігається нерівномірний розвиток пучків твердого лубу, потужна паренхімна та корова частина у вересні порівняно з липнем.

C. multiflora. Реєструються найтиповіші пагони. У жовтні відмічено суттєве зменшення розмірів деревини та діаметра судин.

C. nitens. Відмічено велику товщину перициклічної зони, нечітке та хаотичне розміщення великої кількості судин ксилеми.

C. zabelii. Спостерігається вузька деревна частина, дрібні, іноді недиференційовані судини, здерев'яніння оболонок клітин паренхіми кори.

Пагони всіх п'яти видів досягають відповідного ступеня здерев'яніння тканин у вересні-жовтні, у період фізіологічного спокою до початку несприятливого зимового періоду (табл. 3). Найбільш здерев'янілі в усіх пагонів клітини твердого лубу та ксилеми. Таким чином рослини готуються протистояти зовнішньому тиску у несприятливий зимовий час.

У жовтні відмічено здерев'яніння окремих клітин паренхіми кори у C. zabelii. При порівнянні середнього бала здерев'яніння тканин інших пагонів відмічено, що у C. zabelii він нижчий, ніж, наприклад, у C. lucida на 29 \% і досягає максимального бала (3) тільки у клітин деревини у жовтні. Слід відзначити зворотну залежність між розміром ксилеми та ступенем іiї здерев'яніння. Товщина тканини з часом зменшується, а ступінь її здерев'яніння зростає.

У результаті досліджень інтенсивності крохмальних відкладень у тканинах однорічних пагонів представників роду Cotoneaster Medic. (табл. 4) встановлено, що

Вісник Дніпропетровського університету. Біологія, екологія.

Vìsnik Dnìpropetrovs'kogo unìversitetu. Serìa Bìologiâ, ekologîâ Visnyk of Dnipropetrovsk University. Biology, ecology. Vìsn. Dnìpropetr. Unìv. Ser. Bìol. Ekol. 2007. 15(1).

ISSN 2310-0842 print ISSN 2312-301X online www.ecology.dp.ua 
найінтенсивніші крохмальні відкладення у тканинах пагонів всіх видів спостерігаються у вересні, на початку періоду фізіологічного спокою. У жовтні у більшості пагонів уже відмічено гідроліз крохмалю та зменшення його кількості. Крохмальні зерна стають дрібнішими, їх кількість збільшується у періоді спокою порівняно з фазою вторинного росту. Найбільш крохмаленосними є клітини паренхіми кори та перициклу. Особливо слід відзначити крохмальні відкладення у паренхімі кори у C. multiflora i $C$. nitens.

Табличя 3

Ступінь здерев'яніння тканин однорічних пагонів видів роду Cotoneaster, середній бал

\begin{tabular}{|l|c|c|c|c|}
\hline \multirow{2}{*}{ Вид } & Дата & \multicolumn{3}{|c|}{ Гістологічні комплекси } \\
\cline { 3 - 5 } & відбору & перицикл & твердий луб & ксилема \\
\hline \multirow{3}{*}{ C. horizontalis } & VII.2005 & 1 & 2,5 & 1,5 \\
& IX.2005 & 2,5 & 3 & 3 \\
& X.2005 & 2,5 & 3 & 3 \\
\hline \multirow{3}{*}{ C. lucida } & VII.2005 & 2 & 2 & 2,5 \\
& IX.2005 & 3 & 2 & 2,5 \\
\hline \multirow{3}{*}{ C. multiflora } & X.2005 & 3 & 3 & 1,5 \\
& VII.2005 & 1,5 & 3 & 2,5 \\
\hline \multirow{3}{*}{ C. nitens } & IX.2005 & 2 & 3 & 2,5 \\
& X.2005 & 2 & 3 & 2,5 \\
\hline \multirow{3}{*}{ C. zabeli } & VII.2005 & 1 & 2,5 & 2,5 \\
& IX.2005 & 1,5 & 3 & 2,5 \\
& X.2005 & 2 & 2 & 3 \\
\hline
\end{tabular}

Таблиия 4

Інтенсивність крохмальних відкладень у тканинах однорічних пагонів видів роду Cotoneaster

\begin{tabular}{|l|c|c|c|c|c|}
\hline \multirow{2}{*}{ Вид } & \multirow{2}{*}{ Дата відбору } & \multicolumn{4}{|c|}{ Гістологічні комплекси } \\
\cline { 3 - 6 } & VII.2005 & перицикл & м'який луб & деревина & паренхіма \\
\hline \multirow{3}{*}{ C. horizontalis } & IX.2005 & 0,5 & 0,5 & 1 & 2 \\
& X.2005 & 0 & 1,5 & 0 & 2 \\
\hline \multirow{3}{*}{ C. lucida } & VII.2005 & 0 & 1,5 & 0 & 1,5 \\
& IX.2005 & 0 & 1 & 0 & 3 \\
& X.2005 & 2,5 & 3 & 0,5 & 3 \\
\hline \multirow{3}{*}{ C. multiflora } & VII.2005 & 1,5 & 1 & 1 & 3 \\
& IX.2005 & 3 & 2,5 & 1,5 & 3 \\
\hline \multirow{3}{*}{ C. nitens } & X.2005 & 3 & 2 & 2,5 & 3 \\
& VII.2005 & 3 & 1 & 1 & 3 \\
\hline \multirow{3}{*}{ C. zabelii } & IX.2005 & 2,5 & 1 & 1 & 3 \\
& X.2005 & 3 & 3 & 2 & 2 \\
\hline & VII.2005 & 1 & 0,5 & 0,5 & 2,5 \\
\hline
\end{tabular}

При порівнянні пагонів за середнім балом відмічено, що у видів C. horizontalis, C. lucida, C. zabelii інтенсивність крохмальних відкладень менша за інших, тому вони менше пристосовані до перенесення несприятливих зимових умов і зимового зниження температури. Адже у зимостійких видів накопичення цукрів проходить інтенсивніше, ніж у малостійких.

\section{Висновки}

Більшість пагонів досягають максимального ступеня здерев'яніння у жовтні, у період фізіологічного спокою, а найінтенсивніші крохмальні відкладення - у вересні,

Вісник Дніпропетровського університету. Біологія, екологія.

Vìsnik Dnìpropetrovs'kogo unìversitetu. Serîa Bìologîa, ekologiâ Visnyk of Dnipropetrovsk University. Biology, ecology. Vìsn. Dnìpropetr. Unìv. Ser. Bìol. Ekol. 2007. 15(1).

ISSN 2310-0842 print ISSN 2312-301X online www.ecology.dp.ua 
на початку глибокого спокою. Найпристосованішими до зимового зниження температури виявилися C. horizontalis, C. lucida, C. zabelii. Найінформативніший критерій для визначення стійкості рослин роду Cotoneaster та готовності їх до зимівлі - інтенсивність крохмальних відкладень.

\section{Бібліографічні посилання}

1. Гревцова А. Т. Кизильники. Атлас. - К.: Нива, 1999. - 202 с

2. Гревцова А. Т. Кизильники в Украине / А. Т. Гревцова, Н. А. Казанская. - К.: Нива, 1997. - 192 c.

3. Деревья и кустарники, культивируемые в Украине. Покрытосеменные / Под ред. Н. А. Кохно. - К., 2004. - 640 c.

4. Кучма В. М. Адаптивні властивості деяких інтродукованих видів роду Deutzia Thunb. / В. М. Кучма, Н. Ф. Павлюкова // Інтродукція та захист рослин у ботанічних садах i дендропарках. - Донецьк: Юго-Восток, 2006. - С. 75-79.

5. Нагалевский В. Я. Экологическая анатомия растений / В. Я. Нагалевский, В. Г. Николаевский. - Краснодар: Изд-во КубанГУ, 1981. - 88 с.

6. Паушева 3. П. Практикум по цитологии растений. - М.: Наука, 1981. - 124 с.

7. Рокицкий П. Ф. Биологическая статистика. - Минск: Вышейшая школа, 1973. - 320 с.

8. Фізіологія рослин: Практикум / Під ред. М. М. Мусієнка. - К.: Вища школа, 1995. - 191 с.

9. Фурст Г. Г. Методы анатомо-гистометрического исследования растительных тканей. М.: Наука, 1979. - 156 с.

10. Rehder A. Manual of cultivated trees and shrubs hardy in North America. - N.Y.: Macmillan, 1949. - 996 p.

Надійшла до редколегії 17.12.2006

Вісник Дніпропетровського університету. Біологія, екологія.

Vìsnik Dnìpropetrovs'kogo unìversitetu. Seriâ Bìologiâ, ekologîâ

Visnyk of Dnipropetrovsk University. Biology, ecology. Vìsn. Dnìpropetr. Unìv. Ser. Bìol. Ekol. 2007. 15(1).

ISSN 2310-0842 print ISSN 2312-301X online www.ecology.dp.ua 